\title{
ІДЕНТИФІКАЦІЯ КАТЕГОРІЇ «НАЦІОНАЛЬНІ ДІЛОВІ КУЛЬТУРИ» ЯК ВИХІДНА ОСНОВА МІЖНАРОДНОГО ПІДПРИЕМНИЦТВА
}

\author{
DOI: $10.32620 /$ cher.2020.1.03
}

Постановка проблеми. Кардинальне загострення ситуації на світових товарних, фінансових $\mathrm{i}$ фондових ринках призводить до критичної нестабільності міжнародного підприємництва, що підтверджує необхідність дослідження проблематики національних ділових культур. Мета дослідження

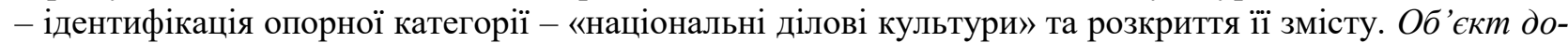
слідження - вихідні гносеологічні засади аналізу та визначальні явища, котрі розкривають зміст категорії - «національні ділові культури». Методи, використані в дослідженні: єдність аналізу та синтезу, сходження від конкретного до абстрактного, метод порівняльного аналізу. Гіпотеза дослідження - національні ділові культури втілюють сукупність явищ і процесів, які є міждисциплінарними за своїм змістом, котрим присутня відтворюваність у часі та просторі з певною модифікацією в конкретних умовах. Виклад основного матеріалу: на підгрунті аналізу праць засновників теорії національних ділових культур (Г. Хофстеде, Ф. Тромпенаарса; Р. Льюїса; К. Рапая) та їх послідовників розглянуто сутність складових дослідження національних ділових культур: крос-культурного менеджменту, крос-культурних комунікацій і крос-культурного маркетингу. Кваліфіковано гносеологічні постулати-вимоги, які є необхідними задля категоріального визначення поняття «національні ділові культури»: багатосферність; детермінантні чинники формування національних ділових культур; довготривалість і відтворення національних ділових культур; властивість ідентифікації та класифікація відмінностей національних ділових культур; модифікація форм проявів національних ділових культур у межах конкретного часу. Оригінальність та практична значимість дослідження полягають у чіткій аутентифікації категорії «національні ділові культури» та виокремленні визначальних складових крос-культурного підприємництва. Висновки та перспективи подальших досліджень: національні ділові культури являють собою складне міждисциплінарне явище, котре фокусує сукупність сутнісних рис не тільки економічного змісту, а й інституціонального середовища. Першочерговими завданнями подальших розробок є проведення прикладних емпіричних досліджень щодо оцінювання національної ділової культури України.

\section{Ключові слова:}

світовий ринок, міжнародне підприємництво, національні ділові культури, інституціональне середовище, крос-культурний менеджмент, крос-культурні комунікації, крос-культурний маркетинг.

\section{IDENTIFICATION OF THE CATEGORY "NATIONAL BUSINESS CULTURES" AS THE ORIGINAL BASIS OF AN INTERNATIONAL ENTREPRENEURSHIP}

Formulation of the problem. The dramatic aggravation of the situation in world commodity, financial and stock markets leads to critical instability of international business, which confirms the need to study the problematics of national business cultures. The aim of the research is to identify the pivotal category - "national business cultures" and to disclose its content. The subject of the research is the original epistemological basis of analysis and the defining phenomena that reveal the content of the category - "national business cultures". The methods of the research: unity of analysis and synthesis, ascent from concrete to abstract, method of comparative analysis. The hypothesis of the research - national business cultures embody a set of phenomena and processes that are multidisciplinary in content, with reproducibility in time and space with some modification in specific conditions. The statement of basic materials: on the basis of the analysis of the works of the founders of the theory of national business cultures (G. Hofstede, F. Trompenaars; R. Lewis; C. Rapaille) and their followers the essence of the components of the study of national business cultures: cross-cultural management, cross-cultural communications and cross-cultural marketing. The epistemologi-

\footnotetext{
${ }^{1}$ Чеботарьов Єгор Вячеславович, канд. екон. наук, доцент кафедри економіки, маркетингу та підприємництва, ДЗ «Луганський національний університет імені Тараса Шевченка», Старобільськ, Україна.

Chebotarov Iegor, Ph.D. in Economics, Associate Professor of Economics, Marketing and Entrepreneurship Department, Luhansk Taras Shevchenko National University, Starobilsk, Ukraine.

ORCID ID: 0000-0001-5963-7637

e-mail: iegor.chebotarov@gmail.com
} 
cal postulates that are necessary for the categorical definition of the "national business cultures" concept are qualified: multifacetedness; determinants of the formation of national business cultures; the longevity and reproduction of national business cultures; property of identification and classification of differences of national business cultures; modification of forms of manifestations of national business cultures within specific time. The originality and practical significance of the research lays in clear authentication of the "national business cultures" category and identification of the defining components of cross-cultural entrepreneurship. Conclusions and perspectives of further research: national business cultures are a complex interdisciplinary phenomenon that focuses on a set of essential features not only of economic content but also of the institutional environment. The primary tasks of further development are to conduct applied empirical studies on the evaluation of Ukraine's national business culture.

Key words:

world market, international entrepreneurship, national business cultures, institutional environment, cross-cultural management, cross-cultural communications, cross-cultural marketing.

\section{ИДЕНТИФИКАЦИЯ КАТЕГОРИИ «НАЦИОНАЛЬНЫЕ ДЕЛОВЫЕ КУЛЬТУРЫ» КАК ИСХОДНАЯ ОСНОВА МЕЖДУНАРОДНОГО ПРЕДПРИНИМАТЕЛЬСТВА}

Постановка проблемы. Кардинальное обострение ситуации на мировых товарных, финансовых и фондовых рынках приводит к критической нестабильности международного предпринимательства, подтверждает необходимость исследования проблематики национальных деловых культур. Цель исследования - идентификация опорной категории - «национальные деловые культуры» и раскрытие ее содержания. Предмет исследования - выходные гносеологические основы анализа и определяющие явления, которые раскрывают содержание категории - «национальные деловые культуры». Методы, использованные в исследовании: единство анализа и синтеза, восхождение от конкретного к абстрактному, метод сравнительного анализа. Гипотеза исследования - национальные деловые культуры воплощают совокупность явлений и процессов, которые являются междисциплинарными по своему содержанию, которым присутствует воспроизводимость во времени и пространстве с определенной модификацией в конкретных условиях. Изложение основного материала: на основе анализа трудов основателей теории национальных деловых культур (Г. Хофстеде, Ф. Тромпенаарса, Р. Льюиса; К. Рапая) и их последователей рассмотрена сущность составляющих исследования национальных деловых культур: кросс-культурного менеджмента, кросс-культурных коммуникаций и кросс-культурного маркетинга. Квалифицированно гносеологические постулатытребования, необходимые для категориального определения понятия «национальные деловые культуры»: многосферность; детерминантные факторы формирования национальных деловых культур; продолжительность и воспроизведение национальных деловых культур; свойство идентификации и классификация различий национальных деловых культур; модификация форм проявлений национальных деловых культур в пределах конкретного времени. Оригинальность и практическая значимость исследования заключаются в четкой аутентификации категории «национальные деловые культуры» и выделении определяющих составляющих кросс-культурного предпринимательства. Bыводы и перспективы дальнейших исследований: национальные деловые культуры представляют собой сложное междисциплинарное явление, которое фокусирует совокупность сущностных черт не только экономического содержания, но и институциональной среды. Первоочередными задачами дальнейших разработок является проведение прикладных эмпирических исследований по оценке национальной деловой культуры Украины.

\section{Ключевые слова:}

мировой рынок, международное предпринимательство, национальные деловые культуры, институциональная среда, кросс-культурный менеджмент, кросс-культурные коммуникации, кросскультурный маркетинг.

Постановка проблеми. Аналіз й узагальнення економічних фактів, явищ і тенденцій розвитку організацій (підприємств, установ, громадських і політичних організацій тощо) окремих країн, груп країн і міжнародних організацій дає теоретико-методологічні та науково-практичні підстави зазначити, що багато з яких проблем значною мірою визначаються характером і властивостями націо- нальних ділових культур тих чи інших країн. Таким чином, у контексті кардинального загострення проблем на світових товарних, фінансових і фондових ринках і загалом - y сфері міжнародного підприємництва, що $\epsilon$ особливо наочним на рубежі другого і третього десятиліть XXI сторіччя, постає комплексна проблема міждисциплінарних компаративних досліджень, основу яких склада- 
ють дослідження в економіці - опрацювання системного знання щодо сутності та змісту національних ділових культур.

На початковому етапі досліджень розгляд окресленої проблеми переводиться у площину визначення іiї вихідних гносеологічних (пізнавальних) засад, чіткої ідентифікації опірної категорії даних досліджень - «національні ділові культури» та розкриття змісту дефініції.

Аналіз останніх дослівджень та публікацій. Проблематика національних ділових культур у науці $є$ недостатньо опрацьованою. Це характерно для усіх країн: і західного (англо-саксонського), і східного (японського), i скандинавського, i арабського, i латиноамериканського світу. Попри наявність окремих продуктивних спроб $[1 ; 2]$, початковий етап досліджень проблематики національних ділових культур є характерним і для колишніх соціалістичних країн, які вже успішно реалізували інтеграційні стратегії свого розвитку. Однак, особливо це стосується України: наукові дослідження за даною тематикою $\mathrm{\epsilon}$ поодинокими [3; 4]. У багатьох інших країнах, i не тільки в країнах колишнього СРСР, дана проблема 3 цілого ряду причин економічного та інституціонального характеру взагалі ще не стала предметом наукових досліджень.

Для переважної більшості сучасних нечисленних компаративних економічних досліджень характерним є наступне: фрагментарне висвітлення питань національних ділових культур, як правило, не виходить за рамки констатації актуальності даної проблематики й загальної констатації визначального внеску в іiі розробку засновників - G. Hofstede [5; 6] i F. Trompenaars [7; 8]. При цьому, подібного роду констатації робляться без предметного аналізу їх підходів і фундаментальних положень теорій.

Найменш опрацьованими складниками загальної досліджуваної проблеми є відсутність чіткого визначення дефініції поняття «національні ділові культури» та класифікації сутнісних характеристик, котрі відображаються у даній категорії. $€$ недостатнім розкриття змісту параметрів ділових культур тих чи інших країн і з'ясування взаємозв'язку (кореспонденціï) цих параметрів в умовах організації та безпосереднього здійснення міжнародної господарської діяльності.

Мета дослідження. Визначальною метою статі $є$ ідентифікація категорії «національні ділові культури». Відповідно до мети, завданнями статі виступають аналіз підходів класиків теорії національних ділових культур та їх найбільш авторитетних послідовників і розкриття змісту опірної дефініції.

Виклад основного матеріалу дослідження. Витоки зародження наукового знання про національні ділові культури у сімдесяті-вісімдесяті роки XX сторіччя беруть початок у розробках відомих менеджерівнауковців Нідерландів G. Hofstede i F. Trompenaars (G. Hofstede часто виокремлюють як одного зі ста найвидатніших менеджерів за всю історію людства).

3 причин об'єктивної актуальності у дев'яності роки дослідження 3 даної тематики в окремих розвинених країнах почали втілюватися у міждисциплінарні розробки вчених і фахівців різних галузей. Переважну частину 3 них було присвячено менеджерським аспектам. Це й стало основою оформлення нового напряму в науці економікс: компаративістики

Спочатку економічна компаративістика виникла як порівняльний або - кроскультурний менеджмент. Крім G. Hofstede i F. Trompenaars відомими представниками менеджерського підходу в дослідженні національних ділових культур (як з позицій західного, так і з позицій східного менеджменту) є Н. Deresky [9], S. Ronen [10] i D. Hickson [11].

Так само на вісімдесяті-дев'яності роки $\mathrm{XX}$ сторіччя припадають розробки ще за одним напрямом проблематики національних ділових культур - крос-культурними комунікаціями. Їх призначення полягає в розкритті змісту комунікативної поведінки в бізнесі носіями різних культур (представниками різних країн), що додатково висунуло й питання психології. Найбільш видатним представником досліджень крос-культурних комунікацій $\epsilon$ відомий англійський учений i практик $\mathrm{R}$. Lewis [12; 13]. Вiн пішов шляхом групування національних ділових культур. Основою виділення таких трьох груп культур стали дві ознаки. Перша - тип підприємницької активності менеджерів тієї чи іншої країни (мульти-активність, лінійно-спрямована активність i реактивність). Друга - психологічний тип відкритості громадян тієї чи іншої країни (інтроверти та екстраверти). Лінійно-активні та реактивні типи підприємницької активності віднесено R. Lewis до інтровертів, а поліактивний тип - до екстравертів.

На підгрунті зазначеного R. Lewis побудував свій знаний трикутник. Верхня вершина цього рівностороннього трикутника - 
країни 3 найбільш вираженою мультиактивної культурою; ліва вершина - країни 3 найбільш вираженою лінійно-активної культурою; права - країни з найбільш вираженою реактивної культурою. За сукупністю цих ознак на катетах трикутника розташовано країни (групи з 2-4 країн) з їх переходом від одного типу до інший.

Вагомий внесок у розробку цього напряму досліджень національних ділових культур внесли також E. Hall [14], D. Victor [15] та A. Inkeles [16]. Дещо пізніше - у дев'яності роки XX та у першому десятилітті XXI сторіччя, оформилися розробки маркетингових аспектів національних ділових культур. Даний напрямок в економічній компаративістиці отримав визначення як крос-культурний маркетинг (він значною мірою охоплював аспекти історії, соціології та культурології).

Є підстави вважати, що найбільш продуктивним й оригінальним у маркетинговому підході став аналіз C. Rapaille [17; 18]. На основі своєрідного синтезу маркетингу, філоcoфiї та психології C. Rapaille вивів поняття «логічна емоційність», «архетип» і «культурний код». Визначальним 3 них, відповідно до підходу C. Rapaille $\epsilon$ «культурний код». Його вчений розуміє як узагальнений образ вираження значень архетипів тієї чи іншої куль- тури; систему сигналів, які кодують для споживача певні явища і значення на ринку.

Будучи послідовником таких видатних вчених-дослідників C. Jung i S. Freud, C. Rapaille первісну основу виникнення i формування «культурного коду країни» бачить у дитячих відчуттях і сприйняттях (своєрідних метаморфозних узагальненнях) найбільш типових представників великих страт (соціальних груп) даної країни. Відомими представниками маркетингового підходу виступають також J. Steenkamp [19], R. Pollay [20].

Тож, дослідження еволюції розробки проблематики національних ділових культур в історії науки дає підстави в їі рамках виокремити три напрями: менеджерський, комунікативний і маркетинговий. Виділені напрями в окремих розвинених країнах логічно оформилися у відповідні відносно самостійні галузі економічного знання й практичної виробничо-комерційної діяльності.

Менеджерський підхід у дослідженні національних ділових культур втілився у крос-культурний менеджмент; комунікативний - у крос-культурні комунікації; маркетинговий - у крос-культурний маркетинг.

Узагальнене відображення порівняльного аналізу зазначених підходів і їх методики викладено у таблиці 1.

Т аблиц я 1

Компаративний аналіз методологічних підходів щодо дослідження національних ділових культур

\begin{tabular}{|c|c|c|c|}
\hline & \multicolumn{3}{|c|}{ Підходи } \\
\hline & Менеджерський & Комунікативний & Маркетинговий \\
\hline Представники & $\begin{array}{l}\text { G. Hofstede, S. Ronen, } \\
\text { F. Trompenaars, } \\
\text { H. Deresky, D. Hickson }\end{array}$ & $\begin{array}{l}\text { R. Lewis, E. Hall, D. Victor } \\
\text { A. Inkeles }\end{array}$ & $\begin{array}{l}\text { C. Rapaille, R. Pollay } \\
\text { J. Steenkamp }\end{array}$ \\
\hline $\begin{array}{c}\text { Використана } \\
\text { методика } \\
\text { (на прикладі } \\
\text { засновників } \\
\text { підходів) }\end{array}$ & $\begin{array}{l}\text { Характеристика націона- } \\
\text { льних ділових культур } \\
\text { на основі виокремлення } \\
\text { двомірних вимірників } \\
\text { («індивідуалізм», «дис- } \\
\text { танція влади», «муж- } \\
\text { ність», «уникнення неви- } \\
\text { значеності», «конфуціа- } \\
\text { нський динамізм») } 3 \text { їх } \\
\text { розглядом у системі ко- } \\
\text { ординат «Сім'я - Школа } \\
\text { - Робота» (G. Hofstede) }\end{array}$ & $\begin{array}{l}\text { Характеристика націона- } \\
\text { льних ділових культур } 3 \\
\text { використанням двох типів } \\
\text { поведінки (інтроверти - } \\
\text { екстраверти) і тривимір- } \\
\text { них характеристик (ліній- } \\
\text { на активність, реактив- } \\
\text { ність, поліактівность) й } \\
\text { побудовою трикутника } 3 \\
\text { розміщенням на його ос- } \\
\text { нові та катетах груп країн } \\
\text { (R. Lewis) }\end{array}$ & $\begin{array}{l}\text { Характеристика націо- } \\
\text { нальних ділових куль- } \\
\text { тур на підгрунті вио- } \\
\text { кремлення типових у } \\
\text { рамах окремих країн } \\
\text { соціальних страт і роз- } \\
\text { криття змісту культур- } \\
\text { них кодів країн на ос- } \\
\text { нові тріади «Логічна } \\
\text { емоційність»-- «Архе- } \\
\text { тип» - «Культурний } \\
\text { код» (С. Rapaille) }\end{array}$ \\
\hline
\end{tabular}

\section{Джерело: розроблено автором}

Для оцінювання національних ділових культур у сучасних умовах, як правило, використовуються такі параметри: «Дистанція влади», «Індивідуалізм», «Мужність», «Уни- кнення невизначеності», «Часова орієнтація», «Індульгенція». Найбільш поширеним даний підхід $є$ у розробках институції Hofstede Insights [21]. При цьому використовується 
також інструментарій оцінки параметрів, характерний для методик обох авторів: оцінка їх крайніх значень від нижчого до вищого 3 кількісним показником по кожній країні.

С підстави зазначити, що наведені параметри виступають як досить аргументований і вдалий синтез теорій G. Hofstede i F. Trompenaars (разом 3 тим, використання для аналізу та оцінок національних ділових культур лише зазначених параметрів вважаємо абсолютно недостатнім). Розгляд вихідних теоретико-методологічних підходів дослідження проблематики національних ділових культур дають підстави зазначити наступне. Категоріальне визначення поняття «національні ділові культури» (його дефініція) має відповідати певним гносеологічним постулатам-вимогам (положенням, установкам). Їх слід розглядати як втілення сутнісних характеристик явищ, процесів, відносин і тенденцій розвитку, котрі мають відображатися даною категорією.

Відповідними гносеологічними постулатами вважаємо такі.

Перший. Детермінантною сутнісною характеристикою категорії «національні ділові культури» має бути іiі багатосферність (багаторівневість).

Таким сферам (рівнями) властива чітка логічна упорядкованість. Внутрішня сфера виступає як визначальна. Це - своєрідне ядро національних ділових культур: система базових (фундаментальних) положень підприємницької діяльності, які закладають сутнісні основи формування та головні механізми реалізації ділової культури тієї чи іншої країни. Ця система базових положень зумовлює похідні сфери національних ділових культур.

Другий. Відповідно до причиннонаслідкової взаємозалежністю явищ, процесів i тенденцій розвитку національних ділових культур, чинники іiі похідних сфер детермінуються чинниками внутрішньої сфери.

Сутнісна характеристика категорії «національні ділові культури» детермінується чинниками економічної сфери (з обов'язковим урахуванням впливу всіх інших чинників життєдіяльності сучасного суспільства).Категорія «національні ділові культури» має відображати сукупність відносин, які $\epsilon$ іманентними - внутрішньо властивими підприємництву (у первісному прояві). Це і вказує на них як на економічні за своєю первісною сутнісною ознакою відносини.
Разом 3 тим, на формування й особливо - на прояв даних відносин, великий вплив має сукупність усіх інших чинників життєдіяльності суспільства: історії, релігії, культури, соціології, політології, науково-технічної та природничо-природної сфер.

Третій. Сутнісною характеристикою категорії «національні ділові культури» має виступати єдність іiі довготривалості та відтворення.

Для національних ділових культур $\mathrm{\epsilon}$ властивою еволюційність визрівання та формування, наявність довгострокових умов i чинників їх подальшого розвитку. Це, як наслідок, зумовлює постійне відтворення характеристик національних ділових культур як у просторі, так й у часі.

Четвертий. Сутнісною характеристикою категорії «національні ділові культури» $€$ властивість ідентифікації іiі характеристик.

Для сукупності явищ, процесів, відносин і тенденцій розвитку, які відображаються в даній категорії стосовно конкретно взятої країни (або - групи країн, близьких за своїми сутнісними параметрами) властива якісна визначеність i, як наслідок, відмінність від інших. Така характеристика виступає підгрунтям ідентифікації, тобто - якісної внутрішньої сутнісної визначеності національної ділової культури конкретної країни (групи країн).

Зазначена ідентифікація, у свою чергу, дозволяє класифікувати відмінності національних ділових культур країн з різними характеристиками (властивостями, параметрами).

П'ятий. Сутнісною характеристикою категорії «національні ділові культури» є об'єктивна певна модифікація форм іiі проявів унаслідок умов, які виникають у межах конкретного часу (у конкретних умовах).

Для відносин, які відображаються цією категорією, як і для будь-яких інших фундаментальних відносин соціально-економічної та інституціональної сфер, цілком логічною $\epsilon$ дія принципу конкретності істини. Це зумовлює залежність національної ділової культури (як окремо взятої країни, так і групи країн близьких за своїми характеристиками) у рамках певних часових періодів від економічних, інституціональних, міжнародних, науковотехнічних та інших умов і чинників, які складаються у межах даних часових періодів.

За підсумком, представлена класифікація гносеологічних постулатів, виступає підгрунтям ідентифікації даної дефініції. 
Тож. Національні ділові культури це структурована система сукупності притаманних базових (сутнісних, фундаментальних) положень підприємницької діяльності, які еволюційно сформувалися і відтворюються у просторі та у часі; ціннісних орієнтирів - поведінкових канонів і норм здійснення підприємництва, а також - традицій, стереотипів, атрибутів, ділової етики та комунікативної поведінки у бізнесі, котра за підсумком є властивою організаціям (підприємствам) певної країни та іiі загальнонаціональному змісту (країни в цілому та/або групі країн, які є близькими за своїми відповідними сутнісними характеристиками).

Висновки та перспективи подальших розробок проблеми. Національні ділові культури являють собою складне міждисциплінарне явище, котре фокусує сукупність сутнісних рис не тільки економічного змісту (економіки, менеджменту, маркетингу), а й історії, релігії, соціології, культури, психології тощо. Недооцінка та/або ігнорування ролі національних ділових культур, тим більше в умовах інтернаціоналізації та глобалізації, призводять до кардинального загострення міжнародної економіки й інституціонального середовища, що наочно підтверджується протягом першого та другого десятиліть сучасного сторіччя.

Першочерговими завданнями розробок у даному напрямі $\epsilon$ проведення прикладних емпіричних досліджень щодо оцінювання національних ділових культур певних країн (насамперед, - України) та розробка пропозицій-рекомендацій бізнесу щодо підвищення ефективності крос-культурного підприємництва.

\section{Література}

1. Тодорова Н.Ю. Кроскультурний менеджмент. Донецьк : ДонНТУ, 2008. 329 с.

3. Пивоваров С.Э., Максимцев И.А. Сравнительный менеджмент. 2-е изд. СПб.: Питер, 2008. $480 \mathrm{c}$.

3. Glinkowska B., Chebotarov V. A. Comparative Cross-Cultural Analysis of the Profile of a Modern Ukrainian Manager: the Imperatives of the Future in the Context of Internationalization. Comparative Economic Research. 2018. 3. Vol. 21. P. 63-74.

4. Glinkowska-Krauze B., Chebotarov Ie., Chebotarov V. Comparative studies of national business cultures in the countries of Central and
Eastern Europe: the basics for Improving International entrepreneurship in Poland and Ukraine. Comparative Economic Research. Central and Eastern Europe. 2020. Vol. 23. № 1. P. 7-18.

5. Hofstede G. Culture and management development. Geneva : International Labour Office, Management Development Branch, Paper MAN, 1983. DEV/28.

6. Hofstede G. Cultural constraints in management theories. Academy of Management Executive. 1993. Vol. 7. No. 1. P. 81-94.

7. Trompenaars F. Riding the waves of culture: Understanding cultural diversity in business. London : Economist Books, 1993. 208 p.

8. Hampden-Turner C., Trompenaars F. The seven cultures of capitalism: Value systems for creating wealth in the United States, Britain, Japan, German, France, Sweden and the Netherlands. London : Little, Brown Book Group, 1995. 416 p.

9. Deresky H. International Management: Management Across Borders and Cultures, 3rd ed., Prentice Hall, Upper Saddle River, NJ., 2000. 614 p.

10. Ronen, S. Comparative and Multinational Management. N.Y. : John Wiley\&Sons, 1986. $656 \mathrm{p}$.

11. Hickson, D. (ed.) Management in Western Europe: Society, culture and organization in twelve nations. Berlin : de Gruyter, 1993. 288 p.

12. Lewis R. Cross Cultural Communication: A Visual Approach, Transcreen Publications, 2008. $287 \mathrm{p}$.

13. Lewis R.D. When Cultures Collide: Managing successfully across cultures, 3nd ed, Nicholas Brealey Publishing, 1999. 336 p.

14. Hall Edward T. The Silent Language. Anchor Books, Reissue edition, 1973. 217 p.

15. Victor, David A. International Business Communication. New York : HarperCollins, 1992. $280 \mathrm{p}$.

16. Inkeles, A., Levinson, D. National character: the study of modal personality and sociocultural systems. Foundations of cross cultural management. Vol. 2. Los Angeles : SAGE. 2008, P. 40-80.

17. Rapaille C. 7 Secrets of Marketing in a Multi-Cultural World, 2nd ed, Tuxedo Production, 2004. $318 \mathrm{p}$.

18. Rapaille C. The Culture Code, Broadway Books, 2007. 213 p.

19. Steenkamp, J.-B.E.M., Ter Hofstede, F. and Wedel, M. A cross-national investigation intothe individual and national cultural antecedents of consumer innovativeness, Journal of Marketing, 1999. Vol. 63 No. 2, P. 55-69. 
20. Pollay, R.W. Measuring the cultural values manifest in advertising, in Leigh, J.H. and Martin, C.R. Jr (Eds), Current Issues and Research in Advertising, Graduate School of Business, Division of Research, University of Michigan, Ann Arbor, MI. 1983. P. 72-92.

21. Hofstede Insights. URL: https://hi.hofstede-insights.com/national-culture. (дата звернення: 10.01.2020р.)

\section{References}

1. Todorova, N.Ju. (2008). Kroskul'turnij menedzhment [Cross Cultural Management]. Donec'k : DonNTU, 329.

2. Pivovarov, S.Je. \& Maksimcev, I.A. (2008). Comparative management. 2-e izd. SPb. : Piter, 480.

3. Glinkowska, B. \& Chebotarov, V. (2018). Comparative Cross-Cultural Analysis of the Profile of a Modern Ukrainian Manager: The Imperatives of the Future in the Context of Internationalization. Comparative Economic Research, 3. Vol. 21. 6374. DOI: $10.2478 /$ cer-2018-0019.

4. Glinkowska-Krauze, B. \& Chebotarov, Ie. \& Chebotarov, V. (2020). Comparative studies of national business cultures in the countries of Central and Eastern Europe: the basics for Improving International entrepreneurship in Poland and Ukraine. Comparative Economic Research. Central and Eastern Europe. Vol. 23, 1, 7-18. http://dx.doi.org/10.18778/1508-2008.23.01.

5. Hofstede, G. (1983). Culture and management development. Geneva: International Labour Office, Management Development Branch, Paper MAN, DEV/28.

6. Hofstede, G. (1993). Ciltural constraints in management theories. Academy of Management Executive. Vol. 7, 1, 81-94.

7. Trompenaars, F. (1993). Riding the waves of culture: Understanding cultural diversity in business. London: Economist Books, 208.

8. Hampden-Turner, C. \& Trompenaars, F. (1995). The seven cultures of capitalism: Value systems for creating wealth in the United States, Britain, Japan, German, France, Sweden and the Netherlands. London : Little, Brown Book Group, 416.

\footnotetext{
Стаття надійшла

до редакції : $12.01 .2020 \mathrm{p}$.
}

9. Deresky, H. (2000). International Management: Management Across Borders and Cultures, 3rd ed., Prentice Hall, Upper Saddle River, NJ, 614.

10. Ronen, S. (1986). Comparative and Multinational Management. N.Y.: John Wiley\&Sons, 656.

11. Hickson, D. (ed.) (1993). Management in Western Europe: Society, culture and organization in twelve nations. Berlin : de Gruyter, 288.

12. Lewis, R. (2008). Cross Cultural Communication: A Visual Approach, Transcreen Publications, 287.

13. Lewis, R.D. (1999). When Cultures Collide: Managing successfully across cultures, 3nd ed, Nicholas Brealey Publishing, 336.

14. Hall Edward, T. (1973). The Silent Language. Anchor Books, Reissue edition, 217.

15. Victor, David A. (1992). International Business Communication. New York : HarperCollins, 280.

16. Inkeles, A. \& Levinson, D. (2008). National character: the study of modal personality and sociocultural systems. Foundations of cross cultural management. Vol. 2. Los Angeles : SAGE, 40-80.

17. Rapaille, C. (2004). 7 Secrets of Marketing in a Multi-Cultural World, 2nd ed, Tuxedo Production, 318.

18. Rapaille, C. (2007). The Culture Code, Broadway Books, 213.

19. Steenkamp, J.-B.E.M. \& Ter Hofstede, F. \& Wedel, M. (1999). A cross-national investigation intothe individual and national cultural antecedents of consumer innovativeness. Journal of Marketing, Vol. 63, 2, 55-69.

20. Pollay, R.W. (1983). Measuring the cultural values manifest in advertising, in Leigh, J.H. \& Martin, C.R. Jr (Eds). Current Issues and Research in Advertising. Graduate School of Business, Division of Research, University of Michigan, Ann Arbor, MI, 72-92.

21. Hofstede Insights. URL: https://hi.hofstede-insights.com/national-culture. (Access date: January 10, 2020).

Стаття прийнята
до друку: 27.02 .2020 p.

Бібліографічний опис для цитування :

Чеботарьов Є. В. Ідентифікація категорії «Національні ділові культури» як вихідна основа міжнародного підприємництва / Є. В. Чеботарьов // Часопис економічних реформ. - 2020. - № 1 (37). - C. 19-25. 